\title{
A poética da crueldade: um olhar no humano e no não humano
}

Angela Guida

Docente no Instituto Superior São José - Santos Dumont, estágio de residência pós-doutoral / UFMG

\begin{abstract}
RESUMO
Tendo como referente a questão da crueldade e sua relação com o Outro, este trabalho terá por objetivo engendrar uma leitura desconstrutivista de princípios cultivados pela metafísica ocidental em torno da relação animal humano e animal não humano, a partir da leitura de produções literárias e filosóficas de autores contemporâneos.
\end{abstract}

\section{PALAVRAS-CHAVE}

Humano, animal, alteridade, crueldade

\author{
"O homem é o mais cruel \\ dos animais." \\ "Se todo animal inspira \\ sempre ternura, que houve, \\ então, com o homem?"”
}

Desde tempos distantes, o humano e o não humano são convocados à representação na literatura, bem como, em outros campos do saber, privilegiando uma ou outra abordagem em consonância com o pensamento da época. Já em Homero a animalidade encontra-se manifesta através de Argos, o cão de Ulisses, que é o único a reconhecer, de imediato, a identidade do antigo dono, quando este retorna a Ítaca oculto sob a pele de um mendigo. Vale lembrar que quando Ulisses partiu, o cão era apenas um filhote. Argos, ao contrário de Penélope, não precisou de uma prova acerca da identidade de Ulisses. Sobre esse episódio, o professor de filosofia da Universidade de São Paulo, Vladimir Safatle, comenta: "Eis um detalhe que não

\footnotetext{
${ }^{1}$ NIETZSCHE. Assim falou Zaratustra, p. 224.

${ }^{2}$ ROSA. Ave palavra, p. 122.
} 
deveria nos deixar indiferentes. Pois ele nos coloca uma questão: haveria algo em nós que só é reconhecido através dos olhos de um animal?”3 Italo Calvino faz semelhante reflexão: “(...) como se a continuidade do indivíduo só se manifestasse por meio de sinais perceptíveis para um olho animal." ${ }^{4}$ Dito de outra maneira, é o que também se interroga Derrida em um de seus mais belos textos, no qual dialoga com a questão da alteridade animal: "Freqüentemente me pergunto, para ver quem sou eu - e quem sou eu no momento em que, surpreendido nu, em silêncio, pelo olhar de um animal." ${ }^{5}$ Ou ainda, como argumenta o filósofo e etólogo, Dominique Lestel, parece que o homem vive mesmo um tempo de tensão no que diz respeito a sua identidade, ao lugar que ocupa frente às outras espécies.

O homem defronta-se com a maior crise de identidade da sua história. Ele alcançou um conhecimento excepcional da sua biologia no contexto de uma representação enferma daquilo que é, de quem é. Uma forma de repensar a identidade humana consiste em repensar as relações do homem com o animal e, por conseguinte, em repensar este último. ${ }^{6}$

De uma forma ou de outra, animal humano e não humano se atravessam. As diferentes mitologias são fartas de seres híbridos, em que um só corpo abriga o humano e o não humano. Aristóteles, com A história dos animais, produz a primeira grande obra acerca da questão do animal; as fábulas cedem espaço à animalidade, a fim de fazer com que o animal humano reconheça sua humanidade/animalidade nas histórias moralizantes; os bestiários ganham especial relevo nos séculos 12 e 13; Descartes, apoiado no discurso da ratio, apresenta-nos a tese do animal-máquina; Darwin recupera a questão da animalidade em sua teoria evolucionista, assim como Buffon, von Uexküll, Bataille, Deleuze e tantos outros. Como se pode perceber, a questão do humano e do não humano e seus limites sempre se fez presente na história da humanidade. Na literatura, há um vasto número de textos que dialogam com o temário da animalidade. É bem verdade que em maior número há os que privilegiam a via da metáfora animal como um caminho para apontar as misérias da raça humana. $\mathrm{O}$ animal não humano se dá tão só como uma ferramenta para revelar ao mundo os vícios e atitudes pouco nobres do animal humano. Assim, de todas as formas de representação da animalidade nos textos literários, uma nos parece mais recorrente: o animal como metáfora do humano, quer pela via da antropomorfização quer pela via da zoomorfização. Só a título de exemplificação

\footnotetext{
${ }^{3}$ SAFATLE. Reconhecido pelo cão, p. 1.

${ }^{4}$ CALVINO. Por que ler os clássicos, p. 21.

${ }^{5}$ DERRIDA. O animal que logo sou, p. 15.

${ }^{6}$ LESTE. As origens animais da cultura, p. 273.
} 
do quanto a metáfora animal tem sido explorada ao longo da literatura como uma questão moralizante, citamos duas produções literárias da mais recente literatura produzida no Brasil: Mastigando humanos, de Santiago Nazarian, e O estranho hábito de dormir em pé, de Paulo Sandrini, em especial, o conto “Dr. Onagro”.

No conto de Paulo Sandrini, a metáfora se dá pela zoomorfização, posto que uma das personagens humanas, o médico Franz, pouco a pouco, vai assumindo as feições de um onagro, um tipo de jumento selvagem nativo da África e da Ásia, numa clara alusão ao comportamento egoísta e bárbaro do vivente humano. Em Mastigando humanos, Santiago Nazarian usa a metáfora pela via da antropomorfização ao nos oferecer um protagonista jacaré, que apresenta todas as características inerentes ao mundo dos viventes humanos. Vitório é um jacaré escritor que vive às voltas com suas crises existenciais e divagações filosóficas, sobretudo a partir do instante em que assume o cargo de professor em uma universidade e depois o de coordenador do departamento de racionalidades da instituição. Ancorado na fala do jacaré, o jovem escritor não economiza críticas à sociedade contemporânea, ao sistema e, por conseguinte, ao vivente humano. Críticas essas que vão desde as comidas servidas em restaurantes fast-food a instituições e saberes acadêmicos: “O conhecimento acadêmico afinal é como um telefone sem fio. Um segue o outro e no final nem se sabe mais sobre o que se está falando. (...) Basta criar termos para manter suas grandes bocas ocupadas e seus cérebros exercitando.”7 No entanto, mesmo perseguindo o percurso de outros escritores que usam o animal não humano para colocar o dedo na ferida dos animais humanos, o texto de Nazarian se diferencia ao subverter a ordem dos pesquisadores nas academias. Na Universidade de Nazarian, os animais não humanos saem da condição de cobaias para assumir as pesquisas, como nos revela o fragmento destacado, no qual o jacaré Vitório conversa com um funcionário humano, tentando entender o porquê de a universidade escolher para pesquisadores os animais não humanos:

- O importante é termos animais estudando animais, porque vocês se entendem melhor. (...) Muito bem, que tal você se tornar professorcoordenador da área de humanidades?

- Como assim? Eu franziria minha testa se tivesse uma.

- Digo, humanidades animais... o caráter humano em vocês... A racionalidade, sim, a racionalidade talvez.

- Mas se é exatamente isso que eu estou questionando, a racionalidade que existe em nós... [animais não humanos]

\footnotetext{
${ }^{7}$ NAZARIAN. Mastigando humanos, p. 156.
} 
- Bem, que seja "Irracionalidade" então. Racionalidade animal, Irracionalidade Humana, são só dois lados da mesma questão. Você poderia coordenar estudos nessas áreas. Dar aulas. Seria legal. Não seria legal? ${ }^{8}$

Evidenciar e/ou denunciar a miséria da raça humana usando os atributos dos animais não humanos, apesar da larga tradição, soa-nos ainda como uma grande reverência ao animal humano em detrimento do animal não humano. Por que se faz necessário revelar o quanto o animal humano tem se desumanizado a partir do lugar do animal não humano? Por que o animal não humano é usado para representar em diferentes formas artístico-literárias comportamentos pouco nobres nos animais humanos? Revelar a degradação do animal humano via animal não humano nos parece demonstrar que se o animal humano não cuidar de sua humanidade, acabará como um animal não humano, animalizado, ou seja, como um ser inferior. Ou pior, a animalidade seria uma forma de punição.

Montaigne comenta que no dogma da metempsicose, isto é, a transmigração de uma alma para outro corpo, além da crença na imortalidade da alma, também havia um componente de justiça divina, uma vez que a escolha dos corpos de animais para onde as almas seriam transportadas dependia da conduta que os humanos haviam tido. Como uma espécie de expiação, as almas seriam aprisionadas aos corpos de animais. Assim, “a que foi cruel no urso, a do ladrão no lobo, a do velhaco na raposa... e depois de ter assim passado por mil metamorfoses, purificadas enfim no rio do Esquecimento, são devolvidas às suas primitivas formas humanas.” ${ }^{\text {A }}$ forma animal seria uma maneira de castigar os humanos que haviam praticado atitudes pouco louváveis. A respeito dessas máscaras animais usadas para denunciar a miséria do animal humano, a professora Ermelinda Ferreira, em "Metáfora animal: a representação do outro na literatura”, argumenta que a representação do animal na literatura moderna ainda carrega certo antropocentrismo, soberania do humano e subjugação do outro absoluto, no caso, o animal não humano. Ainda é um olhar do centro e não a partir da outridade radical. Numa leitura do poema "O bicho", de Manuel Bandeira, a professora destaca a degradação do animal em favor do homem.

O que causa maior choque ao poeta é a abjeção do homem, reduzido às condições de vida que o próprio homem determina como regra para os animais domésticos abandonados na cidade. Apesar do tom de revolta pela situação do humano animalizado, não há a mínima consideração pelas

\footnotetext{
${ }^{8}$ NAZARIAN. Mastigando humanos, p. 155-156.

${ }^{9}$ MONTAIGNE. Da crueldade, p. 368.
} 
condições indignas a que os bichos estão sujeitos, fortemente denunciados no poema à revelia do poeta. ${ }^{10}$

A professora arrola um número significativo de exemplos na literatura brasileira em que o animal, segundo ela, está aprisionado a valores simbólicos humanos e, por conseguinte, desaparece enquanto ele mesmo, perde sua subjetividade. Não obstante, Ferreira lembra que a obra de Clarice Lispector é uma das poucas em que os animais não se esfumaçam nas metáforas: "Ela jamais utiliza os animais para confirmar o homem nem positiva nem negativamente.”11 De fato, em Clarice o animal não humano vai muito além das metáforas, não há subjugação do "completamente outro", como podemos observar no fragmento da crônica "Bichos", quiçá um dos textos em que melhor a autora revela sua relação com a alteridade animal:

Quem se recusa à visão de um bicho está com medo de si próprio.

Mas às vezes me arrepio vendo um bicho. Sim, às vezes sinto o mudo grito ancestral dentro de mim quando estou com eles: parece que não sei mais quem é o animal, se eu ou o bicho, e me confundo toda, fico ao que parece com medo de encarar meus próprios instintos abafados que, diante do bicho sou obrigada a assumir, exigentes como são, que se há de fazer, pobre de nós. Conheci uma mulher que humanizava os bichos, conversando com eles, emprestando-lhes suas próprias características. Mas eu não humanizo os bichos, acho que é uma ofensa - há de respeitar-lhes a natura - eu é que me animalizo. ${ }^{12}$

O percurso de leitura via metáfora animal, apesar de fazer parte das representações literárias desde tempos longínquos, ainda, conforme já o dissemos, parece exprimir certa supremacia do animal humano sobre o animal não humano, sobre o radicalmente Outro. E é esse sentimento de poder, de soberania e de superioridade sobre o Outro que, a nosso ver, abre espaço para as mais diversas manifestações de crueldade quer contra o animal não humano, quer contra o animal humano. Em O animal escrito, Maria Esther Maciel nos convida a uma importante reflexão no que diz respeito à questão da subjugação do vivente não humano pelo animal humano, ao nos lembrar de que a dominação sobre o animal é utilizada para, de certa forma, validar a subjugação de outros seres humanos. Dito de outra maneira, podemos pensar no especismo, de que tanto fala Peter Singer, isto é, qualquer atitude danosa contra um membro de outra espécie, como o racismo e o sexismo, por exemplo, é nociva ao Outro e deve ser tratada como uma questão moral e ética. Para o polêmico filósofo, os humanos se

\footnotetext{
${ }^{10}$ FERREIRA. Metáfora animal: a representação do outro na literatura, p. 128.

${ }^{11}$ FERREIRA. Metáfora animal: a representação do outro na literatura, p. 131.

${ }^{12}$ LISPECTOR. A descoberta do mundo, p. 519-520.
} 
revelam especistas quando subjugam o não humano, minimizam sua capacidade de sofrimento em relação ao animal humano.

Não seria um devaneio supor que a crueldade de toda ordem praticada contra os animais não humanos em nome de uma pretensa superioridade, quiçá a devamos, de certa forma, a Descartes, que, com observações comprovadamente equivocadas, como, por exemplo, a de que o animal não humano é destituído de linguagem, eleva o animal humano na escala das espécies de seres viventes. Segundo o autor do Discurso do método, o animal não humano não é capaz de sentir, uma vez que ele não possui uma alma, uma consciência nem pode fazer uso palavras e de outros sinais para exprimir o que pensa, porque para o filósofo, o ser que pensa é aquele "que duvida, que concebe, que afirma, que nega, que quer, que não quer, que imagina também e que sente”. ${ }^{13}$ Assim, o animal não humano, na leitura de Descartes, por ser privado de linguagem, é um bruto, um autômato, uma máquina, logo, tem seu comportamento, dor, sede, fome, entre outros, explicados por termos puramente mecânicos, o que o coloca decerto numa escala inferior em relação ao animal humano. Não obstante, não são raros os estudos sérios, sobretudo no campo da etologia, que têm desconstruído as certezas do filósofo da ratio e demonstrado que a linguagem se perfaz de diferentes formas. O uso de palavras é só uma entre tantas as maneiras de a linguagem se concretizar. As palavras decerto não garantem supremacia ao animal humano em detrimento do animal não humano. As implicações da leitura limitada de Descartes culminam em uma obviedade que não apresenta consistência: a de que os animais não humanos não são seres sencientes, não sofrem e, com isso, abre-se mais um precedente para a crueldade. Se não se reconhece como legítima a dor do Outro, não se pode reconhecer a crueldade praticada contra esse Outro e o não reconhecimento da crueldade tem trazido consequências catastróficas para todos os seres viventes. A História está aí e não nos deixa mentir.

Já que os animais não humanos são sencientes como os animais humanos, pode-se crer, numa leitura apressada, que a questão seja demonstrar a linha tênue dos limites que nos separam dos animais e realçar os aspectos que nos assemelham a eles e assim garantir a integridade física e quiçá “moral” dos viventes não humanos. Mas a questão não é essa. Pelo contrário. Pensar a animalidade e os limites do humano e do não humano não significa a procura pelas semelhanças entre as referidas espécies. As diferenças existem entre qualquer ser vivente e isso independe da espécie a que ele venha a pertencer. A questão é como abrir-se às diferenças, à alteridade, ao completamente outro, pois “é preciso considerar que existem

\footnotetext{
${ }^{13}$ DESCARTES. Discurso do método, p. 95.
} 
'viventes’ cuja pluralidade não se deixa reunir em uma figura única da animalidade simplesmente oposta à humanidade”. ${ }^{14}$ Exercício de alteridade não rima com o apagamento dos limites. Há diferenças e são elas que marcam a individualidade, a identidade, a subjetividade de cada ser vivente. Encontramo-nos todos sob o signo da diferença ou da différance de Jacques Derrida, filósofo que nos deixou como legado importantes reflexões acerca da outridade no sentido mais absoluto e radical do termo. Desse modo, pensar a animalidade/humanidade quiçá só torna-se mesmo possível por essa via.

O que o motivo da différance tem de universalizável em vista das diferenças é que ele permite pensar o processo de diferenciação para além de qualquer espécie de limites: quer se trate de limites culturais, nacionais lingüísticos ou mesmo humanos. Existe a differánce desde que exista traço vivo, uma relação vida/morte ou presença/ausência. Isso se atuou muito cedo para mim, à imensa problemática da animalidade. ${ }^{15}$

Em Estados-da-alma da psicanálise: o impossível para além da soberana crueldade, Derrida faz uma longa reflexão em torno da questão da crueldade, a partir de um diálogo com Freud e as pulsões de crueldade, de poder e de soberania. Apesar de reconhecer a dificuldade de demarcar ou definir o termo crueldade, uma vez que, segundo ele, semelhante termo encerra grande confusão e obscurantismo, o filósofo recupera duas possibilidades de ocorrência da crueldade: uma de origem latina - cruor, crudus, crudelitas -, que está associada ao derramamento de sangue, e outra que não se encontra ligada ao sanguinário, e sim, a um prazer psíquico no mal e pelo mal, um gozo do mal radical que consiste no "desejo de fazer ou de se fazer sofrer por sofrer”. ${ }^{16}$ Assim, a crueldade, sangrenta ou não, estaria ligada a poder, posse e soberania sobre o Outro e se revelaria como um prazer psíquico de produção do mal. Derrida, amparado pelas reflexões de Freud, ainda observa que não se deve nutrir nenhum tipo de ilusão de que a crueldade possa ser erradicada, posto que ela é parte do homem. No máximo, poderá ser domesticada, apartada, desviada. Em outro texto "Violência contra os animais" -, mesmo reconhecendo a violência a que os animais são submetidos em diferentes níveis, a saber, experimentos científicos, abatedouros, criação industrial, práticas culturais da tauromaquia e tantos outros, o filósofo sente-se tentado, mas prefere não usar o termo crueldade, por ser impreciso e confuso, mas por também crer que ele se encontra atrelado a leis e valores do mundo dos viventes humanos, isto é, ao próprio do

\footnotetext{
${ }^{14}$ DERRIDA. O animal que logo sou, p. 87-88.

${ }^{15}$ DERRIDA. Políticas da diferença, p. 33.

${ }^{16}$ DERRIDA. Estados-da-alma da psicanálise: o impossível para além da soberana crueldade, p. 6. (grifo do autor)
} 
homem. "No fundo, quer se trate do sangue (cruor) ou não (Grausamkeit), a crueldade, o 'fazer sofrer' ou o 'deixar sofrer' pelo prazer, eis ainda o que seria, como referência à lei, o próprio do homem." ${ }^{17}$ No entanto, o filósofo adverte que, independentemente do nome que se dê à violência praticada contra os animais, ela decerto incidirá na imagem que os humanos fazem de si mesmos.

Nietzsche afirmou ser o homem o mais cruel dos animais. Seria a crueldade uma característica presente apenas no animal humano? Se for, que legado para a humanidade! Montaigne, no ensaio “Da crueldade”, comenta o quão é custoso, por exemplo, conceber que há homens que matam pelo mero prazer de praticar tal ato. Segundo o filósofo, o grau máximo de crueldade seria um homem que mata outro homem "sem ser impelido pela cólera ou o medo, e unicamente para o ver morrer". ${ }^{18}$ Uma crueldade que, às vezes, começa contra os viventes não humanos e se estende aos viventes humanos, como argumentam Coetzee e Montaigne: "Ser cruel com os animais pode nos acostumar a ser cruel com os homens.”"19

Os que são sanguinários com os bichos, revelam uma natureza propensa à crueldade. Quando se acostumaram em Roma com os espetáculos de matanças de animais, passaram aos homens e aos gladiadores. A própria natureza, a meu ver, agrega ao homem certa tendência para a inumanidade. ${ }^{20}$

O exercício de alteridade absoluta ainda é um caminho a ser perseguido pelo humano e ele só se dará efetivamente a partir do instante em que o homem for capaz de se sentir no radicalmente Outro. No tocante à crueldade praticada contra os animais não humanos, ela parece se sustentar porque ainda há quem creia que exista uma dor específica para cada espécie de ser vivente, ou pior, ainda há quem ignore a dor e o sofrer do Outro, seja vivente humano ou não humano. As implicações disso deixam, sem dúvida, espaço aberto à crueldade. Em A vida dos animais, de Coetzee, por meio da personagem Elizabeth Costello, Coetzee fala-nos dos poemas de Hughes, poemas esses em que o animal não é representado pela via metafórica. Pelo contrário, há um colocar-se no corpo do animal, um sentir-se no outro radical e vivenciar essa outridade. “(...) Uma poesia que não tenta achar uma idéia no animal, que não é sobre o animal, mas sim, ao contrário, o registro de um compromisso com ele.”21 Esse compromisso com o animal, ou como argumenta Maria Esther Maciel, a

\footnotetext{
${ }^{17}$ DERRIDA. Políticas da diferença, p. 83. (grifos do autor)

${ }^{18}$ MONTAIGNE. Da crueldade, p. 368.

${ }^{19}$ COETZEE. A vida dos animais, p. 28.

${ }^{20}$ MONTAIGNE. Da crueldade, p. 368.

${ }^{21}$ COETZEE. A vida dos animais, p. 61.
} 
exploração de uma subjetividade animal por meio de uma troca física mútua com ela, encontra-se poeticamente explorado, por exemplo, na obra de Clarice Lispector. Maria Esther nos lembra de um episódio em que Clarice narra a sensação trêmula de ter um passarinho nas mãos e daí a professora conclui: “como escrever esse tremor, fazê-lo vibrar na pele das palavras, senão deixando-se possuir pelo passarinho que estremece, metamorfoseando-se momentaneamente nele?”22 Em Guimarães Rosa também nos é possível vislumbrar a exploração da subjetividade animal pela via da interação física, sobretudo no conto "Meu tio Iauretê”, em que o personagem, um caçador de onças, metamorfoseia-se na própria onça. $\mathrm{O}$ personagem vivencia o Outro no corpo do Outro, explora a subjetividade da onça no corpo da onça. "De repente, eh, eu oncei." ${ }^{23}$ E, mesmo correndo o risco de alongar por demais nossos exemplos, não podemos deixar de citar o conto de Mia Couto - “O dono do cão do homem” no qual também nos é possível o vislumbre desse habitar-se no corpo do Outro. A interação física do homem com o cão é tamanha que ele passa a habitar o corpo de seu cão e, num dado momento, já não se sabe mais quem é o cão e quem é o homem: "Feliz, me alojei em toca bruta, numa arrecadação vaga no jardim público. Desfrutando autêntica vida de cão.”24

Outro poético exemplo de alteridade nos chega pela via cinematográfica: a produção fílmica do diretor sul-coreano Kim ki-Duk - Primavera, verão, outono, inverno... e primavera (2003). A nosso ver, um dos mais belos diálogos com a alteridade, com o sentir-se radicalmente no Outro. Um monge vive com seu jovem aprendiz em um monastério flutuante, onde tenta transmitir a ele os valores da filosofia búdica. Certo dia, o pequeno aprendiz vai à floresta e sente grande prazer ao praticar crueldade contra três animais: um peixe, um sapo e uma cobra. Amarra uma pedra ao corpo desses viventes e sorri ao observar o desespero dos três animais para se libertarem das pedras aprisionadas a seus corpos. À noite, enquanto o menino dorme, o monge amarra uma pedra em suas costas, a exemplo do que fizera com os viventes não humanos. No dia seguinte, o menino acorda e não consegue caminhar direito, devido ao peso da pedra. Vai até o monge e reclama, pedindo que retirasse a pedra. O diálogo que se dá entre os dois é um dos mais belos, poéticos e reflexivos diálogos com a alteridade; assim, julgamos pertinente transcrevê-lo na íntegra:

- Ela [a pedra] o incomoda?

-Sim, mestre.

-Você fez o mesmo com os peixes?

\footnotetext{
${ }^{22}$ MACIEL. O animal escrito: um olhar sobre a zooliteratura contemporânea, p. 52.

${ }^{23}$ ROSA. Meu tio o Iauretê, p. 155.

${ }^{24}$ COUTO. O dono do cão do homem, p. 105.
} 
-Sim, mestre.

-Você não fez o mesmo com o sapo?

-Sim, mestre.

-Não fez a mesma coisa com a cobra?

- Sim, mestre.

- Levante-se! Ande um pouco por aí.

- Não consigo andar. É muito pesada.

- Como acha que o peixe, o sapo e a cobra aguentaram?

- Foi errado o que eu fiz.

- Vá procurar os animais e os liberte das pedras e eu o libertarei também. Mas se algum deles: peixe, sapo ou cobra estiver morto... você carregará uma pedra em seu coração pelo resto de sua vida. ${ }^{25}$

O jovem aprendiz, após a conversa com o mestre, sai em busca dos animais, porém consegue libertar apenas o sapo, pois o peixe e a cobra já estavam mortos. Muitos podem objetar e dizer que o menino não possuía consciência da crueldade que praticara. Não estamos tão certos disso, pois diante do velho monge afirma reconhecer que havia agido errado, tanto é que no diálogo com o mestre, ele não pergunta se o que fez fora errado, pelo contrário, afirma. O jovem aprendiz cresce, torna-se adulto, vai embora do monastério, casa-se e, ao sofrer uma desilusão amorosa com a esposa, ele a mata. Partindo das reflexões de Coetzee e Montaigne, dissemos que a crueldade praticada contra os animais não humanos abre uma espécie de precedente para se praticar crueldades contra animais humanos. O filme em questão nos parece corroborar o argumento de Coetzee e Montaigne, afinal o menino, agora homem, comete um assassinato. Mais que isso. Primavera, verão, outono, inverno... e primavera nos permite pensar na mais absoluta experiência de alteridade. Só sabemos quem é o Outro quando nos sentimos radicalmente no Outro. Foi tendo uma pedra presa ao corpo que o aprendiz compreendeu a dor que havia infligido aos animais. Conforme nos diz Heidegger: "Para chegarmos até o outro, precisamos nos sentir no outro."26

Outra produção fílmica que nos permite dialogar com a questão da crueldade praticada contra viventes não humanos e repensar o sentir-se no outro é o filme alemão A alegria de Emma (2006), do cineasta Sven Taddicken. O filme desperta nosso olhar, sobretudo porque não se pode ignorar a maneira como a crueldade é apresentada na produção de Taddicken. Mascarada por um provável sentimento de carinho e de afeto, a crueldade revela-se ainda muito mais cruel, uma vez que se dá sob o pretexto de não provocar sofrimento. É mais ou menos o que diz Derrida acerca da injeção letal usada como um dos instrumentos da aplicação da pena de morte. Dizia-se que ela não era cruel, pois não provocava dor e sofrimento: “Uma

\footnotetext{
${ }^{25}$ PRIMAVERA, verão, outono, inverno... e primavera.

${ }^{26}$ HEIDEGGER. Os conceitos fundamentais da metafísica, p. 234.
} 
crueldade cada vez mais obscena, injusta e bárbara, uma crueldade já não sangrenta, a 'lethal injection'.,27

Emma, a protagonista, é uma jovem camponesa que vive em uma fazenda rodeada por animais. Logo nas cenas iniciais, a jovem brinca com um porco, como se ele fosse um animal de estimação e, em meio às brincadeiras, Emma o conduz para uma área afastada da fazenda, embaixo de uma frondosa árvore. Ali, ela o beija, diz palavras carinhosas, afaga-o e quando o porco está inteiramente entregue aos carinhos dela, passa-lhe uma faca no pescoço, dá mais alguns beijos no porco e depois vai fazer linguiça com sua carne. No decorrer da trama, um forasteiro da cidade, acometido por um câncer terminal no pâncreas, chega à fazenda de Emma. Vivendo no campo com a jovem, Max um dia a surpreende no mesmo ritual com outro porco. Diante da crueldade da cena, Max questiona o porquê de ela agir daquela maneira, isto é, ganhar a confiança do animal para em seguida matá-lo. Emma diz a ele que, quando criança, via seu avô puxar os porcos do chiqueiro com uma corda amarrada no pescoço deles. Eles gritavam desesperadamente, porque sabiam que logo em seguida o avô os mataria, sabiam que iriam morrer e a consciência e o medo da morte eram piores que a própria morte, por isso fazia com que os porcos acreditassem que ela só queria dar a eles afeto e carinho.

Situação semelhante, podemos vislumbrar em Desonra, de Coetzee. Bev Shaw trabalha na clínica “A Liga pelo Bem-Estar dos Animais” e, em meio ao trabalho cotidiano de uma clínica, ela também sacrifica os animais, usando os mesmos artifícios que a personagem de A alegria de Emma. Cobre os animais de carinho e depois tira-lhes a vida. "Os animais confiavam nela, e ela usava essa confiança para sacrificá-los.”28 "Um a um, Bev toca, consola, conversa e sacrifica." 29 Desse modo, pelo desenrolar da trama, tudo leva a crer que a ideia sustentada no filme é a de que uma demonstração de afeto possa ser capaz de minimizar a crueldade de uma navalha circundando um pescoço, seja de um vivente humano ou de um vivente não humano, pois Max, que acaba vivendo um breve romance com Emma, a cada dia fica mais debilitado em virtude de sua doença e pede à jovem que faça com ele o mesmo que fazia com os porcos. Ela não hesita e faz exatamente da mesma maneira. Max pediu a faca em seu pescoço, um caso de eutanásia, mas o os porcos, não. Muitos podem objetar e minimizar a crueldade do gesto de Emma, alegando que os animais criados na fazenda representavam uma

\footnotetext{
${ }^{27}$ DERRIDA. Estados-da-alma da psicanálise: o impossível para além da soberana crueldade, p. 65. (grifos do autor)

${ }^{28}$ COETZEE. Desonra, p. 236.

${ }^{29}$ COETZEE. Desonra, p. 245.
} 
espécie de economia de subsistência e que ela usou o mesmo procedimento com o homem que amava. No entanto, não estamos tão certos disso. Preferimos crer no que diz Derrida acerca das mutações da crueldade: “Existem somente diferenças de crueldade, diferenças de modalidade, de qualidade, de intensidade, de atividade ou de reatividade na mesma crueldade.” ${ }^{30}$ Essa forma “carinhosa” de matar seria apenas uma mutação da crueldade, bem como a pretensa inocência da criança que se diverte com as pedras amarradas aos corpos dos animais no filme de Kim-Ki-Duk.

Coincidência ou não, nas duas produções fílmicas com as quais estamos dialogando, as personagens, antes de matarem um vivente humano, mataram viventes não humanos. A crueldade infligida aos animais não humanos levaria mesmo à prática da crueldade contra viventes humanos, conforme argumentam Coetzee e Montaigne? A obra de Ana Paula Maia Entre rinhas de cachorros e porcos abatidos - parece corroborar a fala dos dois autores. Edgar Wilson, funcionário de um abatedouro, que divide seu tempo entre abater porcos e apostar em rinhas de cães, desde criança fora acostumado a praticar crueldades contra animais não humanos: “foi adestrado desde muito pequeno, matando coelhos e rãs. (...) Edgar sabe que é um cão de briga criado para matar porcos, coelhos e homens."31 Ao longo da narrativa, Edgar Wilson mata muitos porcos e também humanos, utilizando os mesmos métodos de abate tanto para um quanto para outro. Há um fragmento especialmente impactante. Gerson, colega de trabalho de Edgar Wilson, sofre de grave problema renal, porém, no passado, havia doado um de seus rins para sua irmã, mas depois, motivado por Edgar Wilson, decide tomar o rim de volta. Edgar Wilson retalha o corpo de Marinéia em busca do rim de Gerson, exatamente como fazia com os porcos: “- Eu preciso fazer uma marca em volta. Vê se acha algum troço que risque. - Mas pra quê, Edgar? Você abre porcos todos os dias e não precisa dessa frescura de riscar o bicho antes.”32

Entretanto, mesmo sendo simpáticos à ideia de que a crueldade infligida aos viventes não humanos possa se estender aos viventes humanos, há algo nessa proposição que nos inquieta. Quiçá, um pouco semelhante com a defesa que o filósofo e matemático, Pitágoras, faz da abstinência da carne, isto é, não se deve comer a carne de um animal, porque em seu corpo está aprisionada uma alma humana, em decorrência da metempsicose. A não violência contra os animais não humanos deveria se dar por eles mesmos e não porque se corre o risco

\footnotetext{
${ }^{30}$ DERRIDA. Estados-da-alma da psicanálise: o impossível para além da soberana crueldade, p. 74. (grifo do autor)

${ }^{31}$ MAIA. Entre rinhas de cachorros e porcos abatidos, p. 69-70.

${ }^{32}$ MAIA. Entre rinhas de cachorros e porcos abatidos, p. 37.
} 
de haver uma crueldade que possa ser estendida aos animais humanos. Como se pode observar, parece que tudo ainda gira em torno do homem, e não do animal por ele mesmo. A medida ainda é o homem. Ainda não nos abrimos inteiramente ao exercício de alteridade absoluta.

No decorrer deste ensaio, fizemos alusão à justificativa que a jovem camponesa do filme A alegria de Emma dava para a maneira como abatia os porcos de sua fazenda. Assim, fica-nos uma questão: os viventes não humanos, como os humanos, possuem a consciência da morte e, por isso, sentem medo dela? Na conferência enunciada pela personagem de Coetzee, Elizabeth Costello, em reverência à vida dos animais não humanos, um dos participantes contra-argumenta a fala de Costello, ao declarar sua suspeita de que os animais não sentem a morte como os humanos.

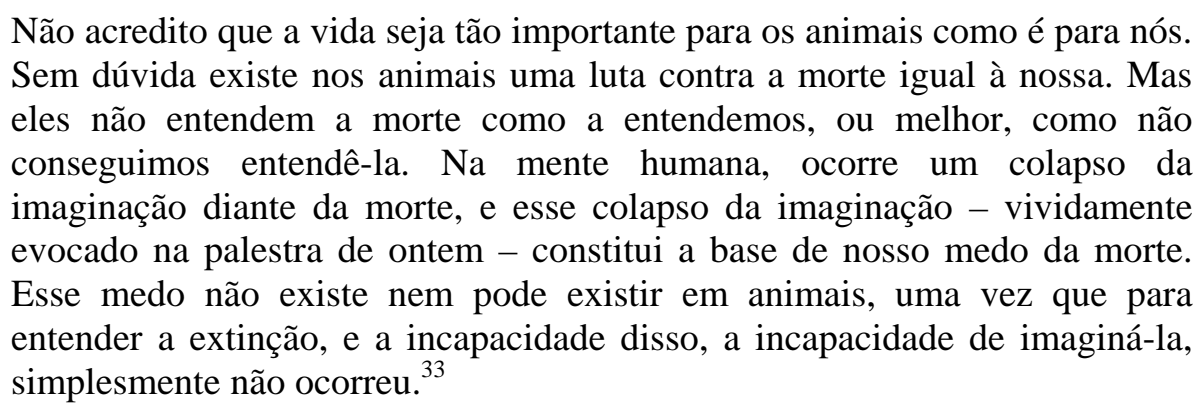

Não são raros os exemplos na literatura que contradizem a fala do oponente intelectual de Elizabeth Costello. Em outro texto de Coetzee, Desonra, o personagem David Lurie observa que os cães sacrificados na clínica “A Liga pelo Bem-Estar dos Animais” sentem que a hora da morte chegou e a maneira como reagem não está ligada a um movimento maquínico, como acreditava Descartes. "Baixam as orelhas, enfiam o rabo entre as pernas, como se também eles sentissem a desgraça que é morrer." 34 No romance Até o dia em que o cão morreu, de Daniel Galera, seu cão, vitimado por um câncer, sente que a morte se aproxima, então, busca consolo ao lado de seu dono. “O cão sentou e começou a ganir muito baixo, quase não dava para ouvir. (...) Passei a mão devagar na sua cabeça, tentando fazer que ele se acalmasse. Aos pouquinhos ele foi se deitando, o corpo cada vez mais mole. Aí eu percebi o que estava acontecendo.”35 Se há no animal não humano consciência da morte ou não, ainda não possuímos argumentos e/ou comprovação científica que possam validar essa questão, no entanto, já existem estudos sérios no campo da etologia que trabalham com a

\footnotetext{
${ }^{33}$ COETZEE. A vida dos animais, p. 76.

${ }^{34}$ COETZEE. Desonra, p. 163

${ }^{35}$ GALERA. Até o dia em que o cão morreu, p. 92.
} 
possibilidade de alguns animais não humanos sofrerem o luto. Pois bem, se sofrem o luto, arriscamos dizer que é porque possuem algum nível de entendimento do que seja a morte.

A professora e etóloga, Ceres Berger Faraco, que pesquisa as relações de interação humano-animal e comportamento animal, argumenta que apenas algumas espécies de viventes não humanos, como os chimpanzés, por exemplo, é que sofrem o luto, ${ }^{36}$ mas que ainda não é possível afirmar que eles sentem a consciência da perda. Mesmo sem a validação científica, aventuramo-nos a dizer que há algo de contraditório, pois o luto só vem quando se sabe que houve a perda. Quiçá se evite usar a denominação consciência, por se tratar de um termo que encerra certa confusão e obscurantismo, a exemplo do termo crueldade. No entanto, se a perda é sentida e manifestada através do luto, de alguma forma, ela passou por algo que se demonstrou presente, seja consciência ou não. A questão é: que nome dar a esse algo? Luto, para Freud, é um dos efeitos da perda. Como se sente a perda se não há consciência daquilo que se perdeu? Como sentir o efeito daquilo que se desconhece? A questão é ampla, complexa e desliza por territórios ainda escorregadios, mas nem por isso deve deixar de ser colocada como um convite à reflexão.

Esperamos ter demonstrado neste breve percurso que a via de leitura filosóficoliterária pelos caminhos da animalidade e dos limites do humano e do não humano ainda tem um longo caminho a perseguir, uma vez que ainda nos cercamos de muitas perguntas e poucas respostas. Apesar de o animal ter estado presente em distintas manifestações artísticas, literárias e filosóficas desde tempos longínquos, nossa relação com a animalidade ainda nos parece atravessada por não raras lacunas. No entanto, esperançosos vislumbramos no estudo dos animais, quem sabe, uma porta aberta para o efetivo exercício da alteridade absoluta, para o efetivo exercício de nos sentirmos radicalmente no Outro. Se não for possível erradicar por completo todas as crueldades infligidas aos animais não humanos e humanos, pois como afirma Derrida, trata-se de uma ilusão, pelo menos, há que se tentar “desviar”, também citando Derrida, as inúmeras crueldades que se tem praticado contra viventes humanos e viventes não humanos ao longo da História e, quem sabe, assim possamos escrever novas páginas da nossa História, páginas que não nos façam, em certos momentos, sentirmos vergonha de pertencermos à raça humana.

\footnotetext{
${ }^{36}$ Ceres Berger nos deu essa informação em diálogos via e-mail.
} 


\begin{abstract}
Using as reference the issue of cruelty and its relations with the Other, this work aims to engender a deconstructive reading of principles cultivated by Western metaphysics regarding the relation human animal and nonhuman animal, from the reading of literary and philosophical productions of contemporary authors.
\end{abstract}

\title{
KEYWORDS
}

Human, animal, alterity, cruelty

\section{REFERÊNCIAS}

A ALEGRIA de Emma. Direção: Sven Taddicken. Comédia dramática. (99min.). Alemanha, 2000.

CALVINO, Italo. Por que ler os clássicos. Trad. Nilson Moulin. São Paulo: Companhia das Letras, 2007.

COETZEE. J. M. A vida dos animais. Trad. José Rubens Siqueira. São Paulo: Companhia das Letras, 2002.

COETZEE. J. M. Desonra. Trad. José Rubens Siqueira. São Paulo: Companhia das Letras, 2000.

COUTO, Mia. O dono do cão do homem. In: O fio das missangas. São Paulo: Companhia das Letras, 2009. p. 103-106.

DERRIDA, Jacques. Estados-da-alma da psicanálise: o impossível para além da soberana crueldade. São Paulo: Escuta Editora, 2001.

DERRIDA, Jacques. O animal que logo sou. Trad. Fábio Landa. São Paulo: Ed. Unesp, 2002. DERRIDA, Jacques. Políticas da diferença. In: De que amanhã. Trad. André Telles. Rio de Janeiro: Jorge Zahar, 2004. p. 32-47.

DERRIDA, Jacques. Violências contra os animais. In: De que amanhã. Trad. André Telles. Rio de Janeiro: Jorge Zahar, 2004. p. 80-96.

DESCARTES, René. Discurso do método. Trad. J. Guinsburg e Bento Prado Júnior. São Paulo: Abril Cultural, 1983. (Os pensadores)

FERREIRA, Ermelinda. Metáfora animal: a representação do outro na literatura. Revista Estudos de Literatura Brasileira Contemporânea, Brasília, n. 26, jul.-dez. 2005.

FREUD, Sigmund. Luto e melancolia. In: . Obras completas de Sigmund Freud. Rio de Janeiro: Edição Standard Brasileira da Imago, 1914-1916. v. XIV.

GALERA, Daniel. Até o dia em que o cão morreu. São Paulo: Companhia das Letras, 2007. HEIDEGGER, Martins. Os conceitos fundamentais da metafísica. Trad. Marco Antônio Casanova. Rio de Janeiro: Forense Universitária, 2006. 
LESTEL, Dominique. As origens animais da cultura. Trad. Maria João Reis. Lisboa: Instituto Piaget, 2001.

LISPECTOR, Clarice. A descoberta do mundo. Rio de Janeiro: Nova Fronteira, 1984.

MACIEL, Maria Esther. O animal escrito: um olhar sobre a zooliteratura contemporânea. São Paulo: Lume, 2007.

MAIA, Ana Paula. Entre rinhas de cachorros e porcos abatidos. Rio de Janeiro: Record, 2009.

MONTAIGNE, Michel. Apologia de Raymond Sebond. In: Os pensadores. Trad. Sérgio Milliet. São Paulo: Nova Cultural, 2000. v. 1. p. 370-504,

MONTAIGNE, Michel. Da crueldade. In: . Ensaios. Trad. Sérgio Milliet. São Paulo: Nova Cultural, 2000. v. 1. p. 358-370. (Os pensadores)

NAZARIAN, Santiago. Mastigando humanos. Rio de Janeiro: Nova Fronteira, 2006.

NIETZSCHE, Friedrich. Assim falou Zaratustra. Trad. Mário da Silva. Rio de Janeiro: Civilização Brasileira, 1981.

PRIMAVERA, verão, outono, inverno... e primavera. Drama. Direção: Kim Ki-Duk. (1h43min), Coreia do Sul, 2003.

ROSA, Guimarães. Ave palavra. Rio de Janeiro: Nova Fronteira, 1985.

ROSA, Guimarães. Estas histórias. Rio de Janeiro: J. Olympio, 1969.

ROSA, Guimarães. Meu tio o Iauretê. In: Estas histórias. Rio de Janeiro: J. Olympio, 1969. p. 126-128.

SAFATLE, Vladimir. Reconhecido pelo cão. Disponível em: <http://revistacult.uol.com.br/home/2011/03/reconhecido-pelo-cao/>. Acesso em: 9 jun. 2011. SANDRINI, Paulo. O estranho hábito de dormir em pé. Curitiba: Travessa dos Editores, 2003. 